Article

\title{
TLR4 T399I Polymorphism and Endometriosis in a Cohort of Italian Women
}

\author{
Enrica Marchionni ${ }^{1, *}+{ }^{+}$, Maria Grazia Porpora ${ }^{2,+} \mathbb{D}$, Francesca Megiorni ${ }^{1}$, Ilaria Piacenti ${ }^{2}$, \\ Agnese Giovannetti ${ }^{3}{ }^{(D)}$, Cinzia Marchese ${ }^{1} \mathbb{D}$, Pierluigi Benedetti Panici ${ }^{2}$ and Antonio Pizzuti ${ }^{1}$ \\ 1 Department of Experimental Medicine, Sapienza University of Rome, Policlinico Umberto I Hospital, \\ 00161 Rome, Italy \\ 2 Department of Maternal and Child Health and Urology, Sapienza University of Rome, \\ Policlinico Umberto I Hospital, 00161 Rome, Italy \\ 3 Laboratory of Clinical Genomics, Fondazione IRCCS Casa Sollievo della Sofferenza, \\ 71013 San Giovanni Rotondo, Italy \\ * Correspondence: enrica.marchionni@uniroma1.it; Tel.: +39-0649974080 \\ + These authors contributed equally to this work.
}

Received: 30 March 2020; Accepted: 24 April 2020; Published: 27 April 2020

\begin{abstract}
Background: Endometriosis is a widespread multifactorial disease in which environmental, genetic, and epigenetic factors contribute to the phenotype. Single Nucleotide Polymorphisms (SNPs) in genes implicated in pivotal molecular mechanisms have been investigated as susceptible risk factors in distinct populations. Among these, Toll-like receptor 4 (TLR4) represents a good candidate due to its role in the immune/inflammatory response and endometriosis pathogenesis. Methods: The TRL4 gene T399I SNP (C/T transition, rs4986791) was investigated in 236 Italian endometriosis patients and 150 controls by using the PCR-RFLP method. One-tailed Fisher's exact test was used to compare differences between categorical variables. T399I genotype distribution was evaluated for Hardy-Weinberg equilibrium in both groups using the Chi-squared test for given probabilities. Results: Fisher's exact test comparing $\mathrm{C}$ and $\mathrm{T}$ allele frequencies showed a difference in the frequency of $\mathrm{T}$ alleles between patients and controls $(\mathrm{OR}=1.96,95 \%$ confidence interval $0.91-4.23$; $p$-value = 0.0552). Genotype frequencies did not show any significant difference between patients and controls. The homozygous TT genotype was observed in $2 \%$ of endometriosis women and not in controls. Conclusions: Our results show that the TLR4 rs4986791 T variant may be considered a genetic risk factor for endometriosis in Italian women. More extensive studies in other populations are needed to confirm this result.
\end{abstract}

Keywords: endometriosis; TLR4; T399I polymorphism

\section{Introduction}

Endometriosis is a gynecological condition characterized by the presence of ectopic endometrial tissue (endometrial glands and stroma) predominantly in the pelvic peritoneum, ovarian and rectovaginal septum and, more rarely, in the diaphragmatic, pleural, and pericardial spaces [1]. The disease is a common health problem affecting up to $10 \%$ of women in reproductive age [2]. The phenotypic manifestations vary from a mild disease with peritoneal involvement to a severe form with both affected ovaries, infiltrating lesions and extensive adhesions [3]. Symptoms are often accompanied by chronic pelvic pain, dysmenorrhea, dyspareunia and reduced fertility [4]. Intensity of pain symptoms varies significantly among patients, not always correlated with the severity of endometriosis. In particular, in women with chronic pelvic pain, psychological consequences may arise, also influencing the perception of pain $[5,6]$. Endometriosis is a multifactorial disorder in which 
environmental, pro-inflammatory, genetic, and epigenetic factors may trigger the specific clinical signs [7].

Twin studies estimated endometriosis heritability at approximately $50 \%$ [8], however, its pathogenesis and pathophysiology have not been fully elucidated so far, although many studies have been conducted to investigate the innate and acquired risk factors.

Many endometriosis susceptibility genes have been detected by Genome Wide Association Studies (GWAS) [9]. GWAS, however, cannot identify genetic specific associations in different populations [10], since there are differences in terms of genetic susceptibility and disease manifestations, as demonstrated by genetic association studies in selective populations [11].

The role of Toll-like receptors (TLRs), which regulate the activation of immune response and inflammation pathways, has been largely investigated in endometriosis [12]. Altered Toll-like receptor 4 (TLR4) expression or function in endometrium was demonstrated in many in vitro and in vivo studies [13-16]. TLR4 is expressed in macrophages, endometrial and endometriotic epithelial cells as well as in stromal cells [17], and it is implicated in the response to exogenous (i.e., Lipopolysaccharide, LPS) [18] or endogenous ligands (i.e., low-density lipoprotein and heat shock proteins) [19]. Recent studies pointed out the involvement of the LPS/TLR4 cascade in the growth regulation in endometriosis tissues [17], since LPS/TLR4 dysfunction may impair the correct mechanism of immune response and favor the onset and progression of the disease. Most studies in different infectious, inflammatory, and autoimmune diseases have focused on two Single Nucleotide Polymorphisms (SNPs) (D299G, rs4986790 and T399I, rs4986791) within the TLR4 gene (OMIM*603030), which have been demonstrated to be (or not) susceptible genetic factors in different populations [20]. The first SNP is an A/G transition causing an Asp/Gly polymorphism at amino acid 299 (D299G; rs4986790) and the second one is a C/T transition causing a Thr/lle polymorphism at amino acid 399 (T399I; rs4986791). The TLR4 D299G SNP has been previously investigated in endometriosis, in Indian [21] and Brazilian [22] cohorts of women. The TRL4 T399I polymorphism, however, has never been investigated in endometriosis patients. The aim of the present study was to clarify the role of the TRL4 T399I polymorphism in this complex genetic scenario, by performing a case-control study comprising an Italian cohort of 236 patients affected by endometriosis and 150 healthy controls.

\section{Materials and Methods}

\subsection{Patients and Controls}

A total of 236 Italian unrelated patients were recruited from the Department of Maternal and Child Health and Urology of Policlinico Umberto I Hospital, Sapienza University of Rome, and were included in the study. All were affected by endometriosis with diagnosis confirmed by laparoscopy and histologic analysis. Stages of disease were classified according to the revised American Society for Reproductive Medicine (rASRM) classification [23]. In the study group, dyspareunia, dysmenorrhea and pelvic pain were investigated using VAS and assigning a score based on the intensity perceived by the patient (0: no pain; $1-4$ : mild; 5-7: moderate; 8-10: severe). As controls, 150 healthy women from the same ethnic origin were enrolled in the study. Pelvic examination and transvaginal ultrasound were performed and resulted normal. Laparoscopy was not performed systematically but, when available, resulted normal in these women.

All subjects gave their informed consent for inclusion before they participated in the study. The study was conducted in accordance with the Declaration of Helsinki, and the protocol was approved (reference code 3545/2015) by the Ethics Committee of The Institutional Review Board of Policlinico Umberto I Hospital. 


\subsection{DNA Extraction and T399I Genotyping}

Genomic DNA was extracted from $5 \mathrm{~mL}$ of peripheral whole-venous blood using a salting out procedure, as previously described [24], and quantified by NanoDrop 2000 (Thermo Fisher Scientific, Inc., Waltham, MA, USA). T399I polymorphism (+1196C/T transition; rs4986791) was typed by the polymerase chain reaction-restriction fragment length polymorphism (PCR-RFLP) method. Briefly, the DNA region comprehending the polymorphism was amplified by PCR by using the TLR4 T399I-forward: 5'-GGTTGCTGTTCTCAAAGTGATTTTGGGAGAA-3' and TLR4 T399I-reverse: 5'-ACCTGAAGACTGGAGAGTGAGTTAAATGCT-3' primers. Amplifications were carried out in a final volume of $30 \mu \mathrm{L}$ including $200 \mathrm{ng}$ of DNA template, primers at $500 \mathrm{nM}$ and $1 \mathrm{U}$ of Taq polymerase (Invitrogen, Carlsbad, CA, USA). PCR conditions were as follows: denaturation for 4 min at $95^{\circ} \mathrm{C}$, 35 cycles of $45 \mathrm{sec}$ at $95^{\circ} \mathrm{C}, 45 \mathrm{sec}$ at $67^{\circ} \mathrm{C}$ and $90 \mathrm{sec}$ at $72{ }^{\circ} \mathrm{C}$, followed by $5 \mathrm{~min}$ at $72{ }^{\circ} \mathrm{C}$. The specific amplificated band of 406 bp was digested by a Hinfl enzyme (New England Biolabs, Ipswich, MA, USA), following the manufacturer's instructions. PCR-RFLP products were separated upon digestion in 3\% NuSieve GTG agarose gels (Lonza Rockland, Rockland, ME, USA) with GelRed Nucleic Acid Gel Stain (Biotium, Fremont, CA, USA) and visualized under Ultraviolet (UV) light by using a ChemiDoc XRS analyzer (Bio-Rad, Hercules, CA, USA).

\subsection{Statistical Analysis}

All statistical analyses were performed with R: A Language and Environment for Statistical Computing (R Core Team, R Foundation for Statistical Computing, Vienna, Austria, 2019) and a $p$-value $<0.05$ was considered statistically significant. The Fisher's exact test was used to compare differences between categorical variables. Odds ratio (OR) and $95 \%$ confidence interval were calculated. T399I genotype distribution was evaluated for Hardy-Weinberg equilibrium in the control group and in the patient group by Chi-squared $\left(\chi^{2}\right)$ test for given probabilities.

\section{Results}

To investigate whether the TRL4 T399I polymorphism (rs4986791) is associated with endometriosis in the Italian population, we performed a case-control study, comparing 236 unrelated patients with 150 healthy women. The mean age in the endometriosis group was 41 years $\pm 9 \mathrm{SD}$. According to the Visual Analogue Scale (VAS), severe or moderate dysmenorrhea was respectively present in $50.3 \%$ and $25.1 \%$ of women with endometriosis, moderate or severe dyspareunia in $16.2 \%$ and $22.0 \%$ and moderate or severe chronic pelvic pain in $15.7 \%$ and $14.7 \%$. Only $17.9 \%$ of these patients were affected by infertility. According to the rASRM classification [23], 2.1\% of women had stage I endometriosis, $7.2 \%$ had stage II, $54.7 \%$ had stage III and $36.0 \%$ had stage IV. Healthy controls $(n=150)$ had a mean age of 35.2 years $\pm 11 \mathrm{SD}$ and did not present a history of endometriosis nor clinical and ultrasonographic signs of this disease. A polymerase chain reaction (PCR) amplicon of $406 \mathrm{bp}$ was obtained, which resulted indigested upon incubation with a Hinfl restriction enzyme in the presence of $C$ nucleotide, whilst was cut in two fragments of 378 and $28 \mathrm{bp}$ when the allele $\mathrm{T}$ was present (data not shown).

Frequency of the $\mathrm{C}$ allele resulted $94 \%$ among patients and $97 \%$ in controls and the frequency of the $\mathrm{T}$ allele resulted $6 \%$ among patients and $3 \%$ in controls. The one tailed $p$-value of the Fisher's exact test comparing the frequencies of the two alleles was $p=0.0552$, showing a slight statistical evidence of difference between endometriosis patients and controls. The OR resulted 1.96 ( $95 \%$ confidence interval 0.91-4.23). The frequency of the three different genotypes did not show any significant differences between patients and controls, however, TT genotype was observed only in women with endometriosis $(2 \%)$. Table 1 summarizes the allele and genotype frequencies of the TRL4 T399I polymorphism in affected and healthy women. 
Table 1. Allele and genotype frequencies of the TLR4 T399I polymorphism in patients with endometriosis and controls. The genetic model was considered dominant in the hypothesis that the T variant is a risk factor for the disease.

\begin{tabular}{ccccc}
\hline TLR4 & \multicolumn{2}{c}{$\begin{array}{c}\text { Patients (236) } \\
\text { n \% }\end{array}$} & \multicolumn{2}{c}{$\begin{array}{c}\text { Controls (150) } \\
\mathbf{n} \%\end{array}$} \\
\hline Allele & \multicolumn{2}{c}{. } & & \\
C & 445 & $(94 \%)$ & 291 & $(97 \%)$ \\
T & 27 & $(6 \%)$ & 9 & $(3 \%)$ \\
Genotype & & & & $(94 \%)$ \\
CC & 213 & $(90 \%)$ & 141 & $(6 \%)$ \\
CT & 19 & $(8 \%)$ & 9 & $(-)$ \\
TT & 4 & $(2 \%)$ & 0 & \\
& & & & $(6 \%)$ \\
Dominant model & 23 & $(10 \%)$ & 9 & $(94 \%)$ \\
CT+TT & 213 & $(90 \%)$ & 141 & \\
CC & & & & \\
\hline
\end{tabular}

In an inheritance model, in which $\mathrm{T}$ is the dominant allele and the risk factor for endometriosis, the prevalence of CT heterozygotes and TT homozygotes, collectively considered, resulted higher in affected women than controls $(10 \%$ vs. $6.0 \%)$ but this difference was not statistically significant (Table 1).

The four TT homozygotes, identified in endometriosis patients only, presented advanced stages of disease according to the rASRM classification [23], two patients in stage III and two in stage IV. Other details on clinical phenotype including VAS, age, Body Mass Index (BMI), other associated diseases and infertility are reported in Table 2. Mean age in homozygous patients (TT genotype) was 43.5 years \pm 9 SD.

The genotype distribution resulted in Hardy-Weinberg equilibrium (HWE) in controls but not in patients.

In the control group, the expected frequency of the three genotypes was $94 \% \mathrm{CC}, 6 \% \mathrm{CT}, 0 \%$ TT and in the observed group was $94 \%$ CC, $6 \%$ CT, $0 \%$ TT $\left(\chi^{2}=0.14348\right.$, d.f. $=2, p$-value $\left.=0.9308\right)$. The $p$-value is higher than 0.05 , suggesting no deviation of HWE in the control group.

In the endometriosis group, the expected frequency of the three genotypes was $89 \%$ CC, $11 \%$ $\mathrm{CT}, 0 \% \mathrm{TT}$, whereas in the observed group was $90 \% \mathrm{CC}, 8 \% \mathrm{CT}, 2 \% \mathrm{TT}\left(\chi^{2}=15.179\right.$, d.f. $=2$, $p$-value $=0.0005057$ ).

Therefore, in the endometriosis group a significant deviation from the HWE ( $p$-value $=0.0005057$ ) was observed, suggesting that differences are not attributed to chance.

Altogether, our results indicate that the presence of the TLR4 rs4986791 T variant may be considered a genetic risk factor for endometriosis. 
Table 2. Clinical characteristics of patients with TT genotype at TLR4 polymorphism.

\begin{tabular}{|c|c|c|c|c|c|c|c|c|c|}
\hline Patient ID & Age & BMI & Dyspareunia * & Dysmenorrhea * & Pelvic Pain * & Infertility & Associated Diseases & Surgery & Stage $* *$ \\
\hline 1 & 35 & 21.1 & mild & moderate & no & no & no & monolateral endometriosic cyst & IV \\
\hline 2 & 54 & 18.4 & no & moderate & no & no & Multiple Sclerosis & monolateral endometriosic cyst & IV \\
\hline 3 & 37 & 22.2 & severe & severe & severe & no & $\begin{array}{l}\text { Irritable Bowel } \\
\text { Syndrome }\end{array}$ & $\begin{array}{c}\text { monolateral endometrioma and } \\
\text { adenomyosis }\end{array}$ & III \\
\hline 4 & 48 & 20 & mild & no & no & no & Gestational Diabetes & $\begin{array}{l}\text { monolateral endometrioma and } \\
\text { peritoneal endometriosis }\end{array}$ & III \\
\hline
\end{tabular}

* Dyspareunia, dysmenorrhea and pelvic pain were investigated using VAS and assigning a score based on the intensity perceived by the patient (0: no pain; 1-4: mild; 5-7: moderate; 8-10: severe). ${ }^{* *}$ Stages of disease were classified according to the rASRM classification [23]. 


\section{Discussion}

Endometriosis is an insidious disorder, often labeled as the "missing disease" [25], with an important diagnostic delay and still lack of resolutive treatments, significantly impacting women's daily lives. It represents a chronic disease, inducing pain and psychological involvement, with negative consequences affecting fertility, sexuality, ability to work, and social and personal relationships [4]. Many women feel that endometriosis controls and limits their lives. Moreover, the need of long-term treatments and the absence of a definitive cure can be contributing factors. The impact of endometriosis is worsened by a lack of understanding of the disease's causes and an increased awareness is needed in society and in research to elucidate its etiopathogenesis.

As for other multifactorial diseases, symptoms and causes of endometriosis are related to an aberrant interplay among genetic, epigenetic, and environmental modifications. The study of genetic backgrounds in different ethnic populations is crucial to better understand these complex interactions. In the last decade, many gene polymorphisms implicated in different molecular pathways have emerged as good candidates to be investigated. Considering the increasing evidence of an inappropriate immunological response in the pathogenesis of several complex disorders, many studies have been conducted to identify the genetic determinants that can modify the immune system. Among these, SNPs in the coding and promoter regions of the human TLR4 gene have been demonstrated to induce a dysregulated TLR4 signaling pathway, this directly correlated to various infectious, autoimmune, allergic, inflammatory diseases, and lastly, endometriosis [20].

Indeed, TLR4 is essential for the innate immune response and it is composed of three domains: an extracellular domain mediating LPS recognition and receptor dimerization, a transmembrane domain and Toll/Interleukin-1 receptor (TIR) domain, which is essential for downstream signal transduction [26]. For the LPS recognition, the extracellular domain of TLR4 is associated with myeloid differentiating protein 2 (MD2), forming a complex and conferring LPS responsiveness to TLR4 [27]. Given its importance in pathogen recognition, TRL4 is highly polymorphic even if its structure is conserved [28]. The extracellular domain shows many sequence variations, such as the D299G and T399I changes, caused by two nonsynonymous and commonly co-segregating SNPs in Caucasian populations [29]. D299G change causes LPS hypo-responsiveness and markedly reduced expression of the protein on the surface of epithelial cells, and T399I change shows a milder LPS-hyporesponsive phenotype [30]. The combined effect of the two SNPs leads to the most severe LPS hypo-responsiveness compared to the responses caused by the single alleles [30]. Consequently, a debated question is how D299G and T399I changes may affect the LPS responsiveness. Preliminary studies have been shown to affect appropriate interaction with agonist or coreceptor [31] or suppressing activation of transcription factors [32]. Crystallography showed that the D299G change may locally disrupt the TLR4 structure, while T399I does not affect the wild type and mutant TLR4 structure [33]. More recent computational approaches of molecular dynamics show that both polymorphisms may abrogate the stability of the hexamer complex, leading to a compromised TLR4 signaling [34]. The role of the two TLR4 SNPs has been largely investigated in many diseases, with genetic association to some infection-related susceptibility, such as Gram-negative caused diseases and septic shock [35,36] or to inflammatory diseases susceptibility, such as Crohn's [37]. Negative studies have been also reported, i.e., in Systemic Lupus Erythematous [38].

In endometriosis patients, a significant increase in TLR4 mRNA expression in ectopic endometriotic lesions compared with corresponding eutopic tissue was reported [13]. Hayashi et al. [15] studied TLR4 expression in endometriosis patients, confirming an increased expression of the TLR4 mRNA and protein in ectopic endometrium compared to eutopic endometrium. A higher expression of TLR4 mRNA was also observed in the menstrual phase in the eutopic endometrium of healthy women, probably as a defense mechanism of the uterus. Both menstrual blood and shed endometrium could be a favorable environment for bacterial infection [15].

The role of the TRL4 D299G polymorphism in determining susceptibility to endometriosis has been previously investigated in two different cohorts of women affected by endometriosis. The first study 
demonstrated an association between the GG genotype and the $G$ allele and the risk of endometriosis in an Indian cohort [21]. Authors hypothesized that in women carrying the TLR4 D299G polymorphism, particularly during the period of menstruation, the retrogradely shed endometrial cells could be implanted on the peritoneum (in the pouch of Douglas) and favorite the onset of endometriosis [21].

The second study, conducted in a Brazilian cohort, did not show significant differences in genotypic or allelic frequencies between patients and controls groups, with no individuals carrying the GG genotype [22]. This discordant finding could be attributed to the different constitution of the two populations, as the worldwide frequencies of TLR4 polymorphisms show distinct patterns of distribution considering different populations and ethnic groups [39].

In the present study, we used a case-control approach to assess if TLR4 T399I polymorphism is a susceptibility factor to endometriosis in Italian women. Our data suggest an association of the $\mathrm{T}$ allele with endometriosis disease, showing a 1.96-fold increased OR when evaluating patients and controls. Interestingly, homozygous TT genotype was only observed in women with endometriosis, but not in healthy females, even if the comparison did not result significant. However, considering the frequency of endometriosis and the Minor Allele Frequency (MAF) of the TLR4 T399I SNP, the lack of significant association between genotype and endometriosis risk may be due to the relatively low number of analyzed women, this representing the main limit of the present research. More extensive studies, also involving other genetic variations in the TLR4 gene as well as replication in larger number of patients and in different populations, will be needed to confirm our observations. Interrogation of the Genome Aggregation Database (gnomAD, v.2.1.1), the largest population database to date, in 140,863 available individuals, T399I shows an overall MAF of 6\%, ranging from $1 \%$ in Africans to $6 \%$ in Europeans (non-Finnish) and 10\% in Finnish. In gnomAD, TT homozygotes are very rare $(0.4 \%)$. On the contrary, in our cohort of patients, homozygotes have a frequency of almost $2 \% \mathrm{vs} .0 \%$ in the control group.

The four TT homozygous patients did not show a specific association neither with higher VAS scores for dyspareunia, dysmenorrhea and pelvic pain, nor with infertility (Table 2). Nonetheless, all the TT patients presented advanced stages of endometriosis (III and IV, Table 2), this suggesting that the T399I polymorphism might be involved in the progression and severity of the disease but future studies and functional analyses are needed to demonstrate our hypothesis.

Table 3 summarizes some details on the genetic relationship between the TLR4 gene and endometriosis in Indian [21], Brazilian [22] and Italian populations (present research).

Table 3. TLR4 SNPs in endometriosis patients and controls in different populations.

\begin{tabular}{|c|c|c|c|c|}
\hline$T L R 4$ SNPs [Ref] & $\begin{array}{c}\text { Endometriosis } \\
\text { Group }\end{array}$ & Control Group & $p$-Value $\left(\chi^{2}\right)$ & $\begin{array}{c}\text { Odds Ratio } \\
\text { (Confidence Interval) }\end{array}$ \\
\hline \multirow{2}{*}{$\begin{array}{l}\text { rs4986790 A/G [21] } \\
\text { Indian population } \\
\text { Allele frequency }\end{array}$} & $N=200$ & $N=200$ & & \\
\hline & $A=89 \% G=11 \%$ & $A=97 \% G=3 \%$ & $p<0.05$ & $\mathrm{OR}=4.48(95 \%$ CI $2.28-8.80)$ \\
\hline \multirow{2}{*}{$\begin{array}{l}\text { rs4986790 A/G [22] } \\
\text { Brazilian population } \\
\text { Allele frequency }\end{array}$} & $n=100$ & $n=100$ & & \\
\hline & $A=96 \% G=4 \%$ & $A=95 \% G=5 \%$ & ns & ns \\
\hline \multirow{2}{*}{$\begin{array}{c}\text { rs4986791 C/T } \\
\text { present study, Italian population } \\
\text { Allele frequency }\end{array}$} & $n=236$ & $n=150$ & & \\
\hline & $\mathrm{C}=94 \% \mathrm{~T}=6 \%$ & $\mathrm{C}=97 \% \mathrm{~T}=3 \%$ & $p=0.0552$ & $\mathrm{OR}=1.96(95 \%$ CI $0.91-4.23)$ \\
\hline
\end{tabular}

In previous studies of Italian cohorts of endometriosis patients, environmental factors [40], as well as different SNPs in other genes were investigated [41-44]. More recently, in a Mediterranean cohort of patients (Sardinian population), no significant association was observed for three SNPs present in WNT4, VEZT and FSHB genes (rs7521902, rs10859871 and rs11031006, respectively), which have been previously identified as risk factors for endometriosis in other populations [45]. Both negative and positive results are important to shed light on risk factors of this complex disease.

According to our observation, the TLR4 polymorphisms and the related inflammation pathways seem to be good candidates to further investigations. Many studies have linked genetic variations in TLR4 with susceptibility to different infectious and inflammatory diseases, with complex interactions 
depending on environmental factors, ethnic backgrounds, and multigenic effects [20], probably involving different gene networks.

The identification of genetic risk factors in specific populations may better elucidate their effects and their possible roles in disease prognosis and prevention [46].

To date, in endometriosis patients, diagnosis delays and limited effectiveness of treatments are well known issues, causing negative impacts on women's quality of life. In multifactorial diseases such as endometriosis, the genetic contribution to the phenotype depends on the combination of alleles, and multiple genetic interactions in different pathways contribute to disease susceptibility and possibly correlate with specific phenotypes in terms of disease severity, progression and associated symptoms. Identifying genetic risk factors could improve the management and prevention of physical and psychological complications of a specific disorder.

In conclusion, our data indicate the association of the TLR4 rs4986791 T allele with endometriosis in an Italian cohort of women, this supporting the role of genetic variations in the modulation of the TLR4-mediated immune response in endometriosis disease.

Author Contributions: Study conceptualization, E.M. and M.G.P.; methodology, F.M.; software and formal analysis, I.P. and A.G.; data and patient management, E.M., I.P. and A.G.; writing-original draft preparation, E.M. and F.M.; manuscript supervision, M.G.P., C.M., P.B.P. and A.P.; project administration A.P. All authors have read and agreed to the published version of the manuscript

Funding: This research received no external funding.

Acknowledgments: We are grateful to the patients and controls for their participation.

Conflicts of Interest: The authors declare no conflict of interest.

\section{Abbreviations}

$\begin{array}{ll}\text { SNP } & \text { Single Nucleotide Polymorphism } \\ \text { TLR4 } & \text { Toll-like receptor } 4 \\ \text { C/T } & \text { Cytosine to Thymine } \\ \text { PCR-RFLP } & \text { Polymerase Chain Reaction-Restriction Fragment Length Polymorphism } \\ \text { Thr/Ile } & \text { Threonine to Isoleucine } \\ \text { T399I } & \text { Threonine 399 to Isoleucine } \\ \text { OR } & \text { Odds Ratio } \\ \text { GWAS } & \text { Genome Wide Association Study } \\ \text { TLRs } & \text { Toll-like receptors } \\ \text { LPS } & \text { Lipopolysaccharide } \\ \text { LPS/TLR4 } & \text { Lipopolysaccharide/Toll-like receptor 4 } \\ \text { A/G } & \text { Adenine to Guanine } \\ \text { Asp/Gly } & \text { Aspartate to Glycine } \\ \text { D299G } & \text { Aspartate 299 to Glycine } \\ \text { SD } & \text { Standard Deviation } \\ \text { bp } & \text { base pair } \\ \text { HWE } & \text { Hardy-Weinberg equilibrium } \\ \text { ASRM } & \text { American Society for Reproductive Medicine } \\ \text { BMI } & \text { Body Mass Index } \\ \text { VAS } & \text { Visual Analogue Scale } \\ \text { TIR } & \text { Toll/Interleukin-1 receptor } \\ \text { MD2 } & \text { Myeloid Differentiating protein 2 } \\ \text { MAF } & \text { Minor Allele Frequency } \\ \text { gnomAD } & \text { Genome Aggregation Database } \\ \text { WNT4 } & \text { Wingless-Type MMTV Integration Site Family Member 4 gene } \\ \text { VEZT } & \text { Vezatin gene } \\ \text { FSHB } & \text { Follicle-Stimulating Hormone Beta Polypeptide gene } \\ \text { UV } & \text { Ultraviolet } \\ & \end{array}$




\section{References}

1. Dunselman, G.A.; Vermeulen, N.; Becker, C.; Calhaz-Jorge, C.; D’Hooghe, T.; De Bie, B.; Heikinheimo, O.; Horne, A.W.; Kiesel, L.; Nap, A.; et al. European Society of Human Reproduction and Embryology. ESHRE guideline: Management of women with endometriosis. Hum. Reprod. 2014, 29, 400-412. [CrossRef]

2. Burney, R.O.; Giudice, L.C. Pathogenesis and pathophysiology of endometriosis. Fertil. Steril. 2012, 98, 511-519. [CrossRef] [PubMed]

3. Czyzyk, A.; Podfigurna, A.; Szeliga, A.; Meczekalski, B. Update on endometriosis pathogenesis. Minerva Ginecol. 2017, 69, 447-461. [CrossRef] [PubMed]

4. Moradi, M.; Parker, M.; Sneddon, A.; Lopez, V.; Ellwood, D. Impact of endometriosis on women's lives: A qualitative study. BMC Women's Health 2014, 14, 123. [CrossRef]

5. Lorençatto, C.; Petta, C.A.; Navarro, M.J.; Bahamondes, L.; Matos, A. Depression in women with endometriosis with and without chronic pelvic pain. Acta Obstet. Gynecol. Scand. 2006, 85, 88-92. [CrossRef]

6. Cavaggioni, G.; Lia, C.; Resta, S.; Antonielli, T.; Benedetti Panici, P.; Megiorni, F.; Porpora, M.G. Are mood and anxiety disorders and alexithymia associated with endometriosis? A preliminary study. Biomed. Res. Int. 2014, 786830. [CrossRef]

7. Deiana, D.; Gessa, S.; Anardu, M.; Daniilidis, A.; Nappi, L.; D’Alterio, M.N.; Pontis, A.; Angioni, S. Genetics of endometriosis: A comprehensive review. Gynecol. Endocrinol. 2019, 35, 553-558. [CrossRef] [PubMed]

8. Saha, R.; Pettersson, H.J.; Svedberg, P.; Olovsson, M.; Bergqvist, A.; Marions, L.; Tornvall, P.; Kuja-Halkola, R. Heritability of endometriosis. Fertil. Steril. 2015, 104, 947-952. [CrossRef]

9. Sapkota, Y.; Steinthorsdottir, V.; Morris, A.P.; Fassbender, A.; Rahmioglu, N.; De Vivo, I.; Buring, J.E.; Zhang, F.; Edwards, T.L.; Jones, S.; et al. Meta-analysis identifies five novel loci associated with endometriosis highlighting key genes involved in hormone metabolism. Nat. Commun. 2017, 8, 15539. [CrossRef]

10. Rahmioglu, N.; Nyholt, D.R.; Morris, A.P.; Missmer, S.A.; Montgomery, G.W.; Zondervan, K.T. Genetic variants underlying risk of endometriosis: Insights from meta-analysis of eight genome-wide association and replication datasets. Hum. Reprod. Update 2014, 20, 702-716. [CrossRef] [PubMed]

11. Matalliotakis, M.; Zervou, M.I.; Matalliotaki, C.; Rahmioglu, N.; Koumantakis, G.; Kalogiannidis, I.; Prapas, I.; Zondervan, K.; Spandidos, D.A.; Matalliotakis, I.; et al. The role of gene polymorphisms in endometriosis. Mol. Med. Rep. 2017, 16, 5881-5886. [CrossRef]

12. Khan, K.N.; Kitajima, M.; Fujishita, A.; Nakashima, M.; Masuzaki, H. Toll-like receptor system and endometriosis. J. Obstet. Gynaecol. Res. 2013, 39, 1281-1292. [CrossRef] [PubMed]

13. Allhorn, S.; Böing, C.; Koch, A.A.; Kimmig, R.; Gashaw, I. TLR3 and TLR4 expression in healthy and diseased human endometrium. Reprod. Biol. Endocrinol. 2008, 6, 40. [CrossRef] [PubMed]

14. Sheldon, I.M.; Roberts, M.H. Toll-like receptor 4 mediates the response of epithelial and stromal cells to lipopolysaccharide in the endometrium. PLOS ONE 2010, 5, e12906. [CrossRef]

15. Hayashi, C.; Chishima, F.; Sugitani, M.; Ichikawa, G.; Nakazawa-Watanabe, T.; Sugita, K.; Suzuki, M.; Nemoto, N.; Yamamoto, T. Relationship between Toll-like receptor-4 and mPGES-1 gene expression in local lesions of endometriosis patients. Am. J. Reprod. Immunol. 2013, 69, 231-239. [CrossRef] [PubMed]

16. Koval, H.; Chopiak, V.; Kamyshnyi, A. mRNA TLR2 and TLR4 expression in the endometrium tissue in women with endometriosis associated with infertility. Georgian Med. News 2015, 7-11, 244-245.

17. Khan, K.N.; Fujishita, A.; Hiraki, K.; Kitajima, M.; Nakashima, M.; Fushiki, S.; Kitawaki, J. Bacterial contamination hypothesis: A new concept in endometriosis. Reprod. Med. Biol. 2018, 17, 125-133. [CrossRef]

18. Aderem, A.; Ulevitch, R.J. Toll-like receptors in the induction of the innate immune response. Nature 2000, 406, 782-787. [CrossRef]

19. Wallin, R.P.A.; Lundqvist, A.; More, S.H.; von Bonin, A.; Kiessling, R.; Ljunggren, H.G. Heatshock proteins as activators of the innate immune system. Trends Immunol. 2002, 23, 130-135. [CrossRef]

20. Medvedev, A.E. Toll-like receptor polymorphisms, inflammatory and infectious diseases, allergies, and cancer. J. Interferon Cytokine Res. 2013, 33, 467-484. [CrossRef]

21. Latha, M.; Vaidya, S.; Movva, S.; Chava, S.; Govindan, S.; Govatati, S.; Banoori, M.; Hasan, Q.; Kodati, V.L. Molecular pathogenesis of endometriosis; Toll-like receptor-4 A896G (D299G) polymorphism: A novel explanation. Genet. Test. Mol. Biomark. 2011, 15, 181-184. [CrossRef] 
22. De Oliveira Francisco, D.; de Paula Andres, M.; Gueuvoghlanian-Silva, B.Y.; Podgaec, S.; Fridman, C. CCDC22 gene polymorphism is associated with advanced stages of endometriosis in a sample of Brazilian women. J. Assist. Reprod. Genet. 2017, 34, 939-944. [CrossRef] [PubMed]

23. Revised American Society for Reproductive Medicine classification of endometriosis: 1996. Fertil. Steril. 1997, 67, 817-821. [CrossRef]

24. Latiano, A.; Mora, B.; Bonamico, M.; Megiorni, F.; Mazzilli, M.C.; Cucchiara, S.; Palmieri, O.; Valvano, M.R.; Annese, V. Analysis of candidate genes on chromosomes $5 \mathrm{q}$ and $19 \mathrm{p}$ in coeliac disease. J. Pediatr. Gastroenterol. Nutr. 2007, 45, 180-186. [CrossRef] [PubMed]

25. Overton, C.; Park, C. Endometriosis. More on the missed disease. BMJ 2010, 341, c3727. [CrossRef] [PubMed]

26. Akira, S.; Takeda, K. Toll-like receptor signalling. Nat. Rev. Immunol. 2004, 4, 499-511. [CrossRef] [PubMed]

27. Nagai, Y.; Akashi, S.; Nagafuku, M.; Ogata, M.; Iwakura, Y.; Akira, S.; Kitamura, T.; Kosugi, A.; Kimoto, M.; Miyake, K. Essential role of MD-2 in LPS responsiveness and TLR4 distribution. Nat. Immunol. 2002, 3, 667-672. [CrossRef]

28. Smirnova, I.; Poltorak, A.; Chan, E.K.; McBride, C.; Beutler, B. Phylogenetic variation and polymorphism at the toll-like receptor 4 locus (TLR4). Genome Biol. 2000, 1, RESEARCH002. [CrossRef]

29. Schröder, N.W.; Schumann, R.R. Single nucleotide polymorphisms of Toll-like receptors and susceptibility to infectious disease. Lancet Infect. Dis. 2005, 5, 156-164. [CrossRef]

30. Arbour, N.C.; Lorenz, E.; Schutte, B.C.; Zabner, J.; Kline, J.N.; Jones, M.; Frees, K.; Watt, J.L.; Schwartz, D.A. TLR4 mutations are associated with endotoxin hyporesponsiveness in humans. Nat. Genet. 2000, 25, 187-191. [CrossRef]

31. Rallabhandi, P.; Bell, J.; Boukhvalova, M.S.; Medvedev, A.; Lorenz, E.; Arditi, M.; Hemming, V.G.; Blanco, J.C.; Segal, D.M.; Vogel, S.N. Analysis of TLR4 polymorphic variants: New insights into TLR4/MD-2/CD14 stoichiometry, structure, and signaling. J. Immunol. 2006, 177, 322-332. [CrossRef]

32. Figueroa, L.; Xiong, Y.; Song, C.; Piao, W.; Vogel, S.N.; Medvedev, A.E. The Asp299Gly Polymorphism Alters TLR4 Signaling by Interfering with Recruitment of MyD88 and TIR domain-containing adapter inducing IFN- $\beta$. J. Immunol. 2012, 188, 4506-4515. [CrossRef]

33. Ohto, U.; Fukase, K.; Miyake, K.; Shimizu, T. Structural basis of species-specific endotoxin sensing by innate immune receptor TLR4/MD-2. Proc. Natl. Acad. Sci. USA 2012, 109, 7421-7426. [CrossRef] [PubMed]

34. Anwar, M.A.; Choi, S. Structure-Activity Relationship in TLR4 Mutations: Atomistic Molecular Dynamics Simulations and Residue Interaction Network Analysis. Sci. Rep. 2017, 7, 43807. [CrossRef] [PubMed]

35. Lorenz, E.; Mira, J.P.; Frees, K.L.; Schwartz, D.A. Relevance of mutations in the TLR4 receptor in patients with gram-negative septic shock. Arch. Intern. Med. 2002, 162, 1028-1032. [CrossRef] [PubMed]

36. Agnese, D.M.; Calvano, J.E.; Hahm, S.J.; Coyle, S.M.; Corbett, S.A.; Calvano, S.E.; Lowry, S.F. Human toll-like receptor 4 mutations but not $\mathrm{CD} 14$ polymorphisms are associated with an increased risk of gram-negative infections. J. Infect. Dis. 2002, 186, 1522-1525. [CrossRef] [PubMed]

37. Fu, Z.; Shen, Y.; Lin, L.; Chen, Y.; Li, Y.; Que, R. Association between Toll-Like Receptor 4 T399I Gene Polymorphism and the Susceptibility to Crohn's Disease: A Meta-Analysis of Case-Control Studies. Digestion 2018, 97, 250-259. [CrossRef]

38. Hu, W.; Wu, S.; Zhang, Y.; Sigdel, K.R.; Lin, Y.; Zhong, H. Association between Toll-Like Receptor 4 Polymorphisms and Systemic Lupus Erythematosus Susceptibility: A Meta-Analysis. Biomed. Res. Int. 2016, 2016, 7842587. [CrossRef]

39. Ferwerda, B.; McCall, M.B.; Alonso, S.; Giamarellos-Bourboulis, E.J.; Mouktaroudi, M.; Izagirre, N.; Syafruddin, D.; Kibiki, G.; Cristea, T.; Hijmans, A.; et al. TLR4 polymorphisms, infectious diseases, and evolutionary pressure during migration of modern humans. Proc. Natl. Acad. Sci. USA 2007, 104, 16645-16650. [CrossRef]

40. Porpora, M.G.; Medda, E.; Abballe, A.; Bolli, S.; De Angelis, I.; di Domenico, A.; Ferro, A.; Ingelido, A.M.; Maggi, A.; Panici, P.B.; et al. Endometriosis and organochlorinated environmental pollutants: A case-control study on Italian women of reproductive age. Environ. Health Perspect. 2009, 117, 1070-1075. [CrossRef]

41. Gentilini, D.; Somigliana, E.; Vigano, P.; Vignali, M.; Busacca, M.; Di Blasio, A.M. The vascular endothelial growth factor $+405 \mathrm{G}>\mathrm{C}$ polymorphism in endometriosis. Hum. Reprod. 2008, 23, 211-215. [CrossRef] [PubMed] 
42. Vichi, S.; Medda, E.; Ingelido, A.M.; Ferro, A.; Resta, S.; Porpora, M.G.; Abballe, A.; Nisticò, L.; De Felip, E.; Gemma, S.; et al. Glutathione transferase polymorphisms and risk of endometriosis associated with polychlorinated biphenyls exposure in Italian women: A gene-environment interaction. Fertil. Steril. 2012, 97, 1143-1151. [CrossRef] [PubMed]

43. Pagliardini, L.; Gentilini, D.; Vigano', P.; Panina-Bordignon, P.; Busacca, M.; Candiani, M.; Di Blasio, A.M. An Italian association study and meta-analysis with previous GWAS confirm WNT4, CDKN2BAS and FN1 as the first identified susceptibility loci for endometriosis. J. Med. Genet. 2013, 50, 43-46. [CrossRef] [PubMed]

44. Megiorni, F.; Resta, S.; Yazdanian, D.; Cavaggioni, G.; Lia, C.; Benedetti Panici, P.; Pizzuti, A.; Porpora, M.G. Lack of association between serotonin transporter 5-HTT gene polymorphism and endometriosis in an Italian patient population. J. Negat. Results Biomed. 2014, 13, 12. [CrossRef]

45. Angioni, S.; D'Alterio, M.N.; Coiana, A.; Anni, F.; Gessa, S.; Deiana, D. Genetic Characterization of Endometriosis Patients: Review of the Literature and a Prospective Cohort Study on a Mediterranean Population. Int. J. Mol. Sci. 2020, 21, 1765. [CrossRef]

46. Trejo-de la, O.A.; Hernández-Sancén, P.; Maldonado-Bernal, C. Relevance of single-nucleotide polymorphisms in human TLR genes to infectious and inflammatory diseases and cancer. Genes Immun. 2014, 15, 199-209. [CrossRef]

(C) 2020 by the authors. Licensee MDPI, Basel, Switzerland. This article is an open access article distributed under the terms and conditions of the Creative Commons Attribution (CC BY) license (http://creativecommons.org/licenses/by/4.0/). 